\title{
Self-Care Management in Myofascial Pain Dysfunction Syndrome
}

ISSN: 2637-7764

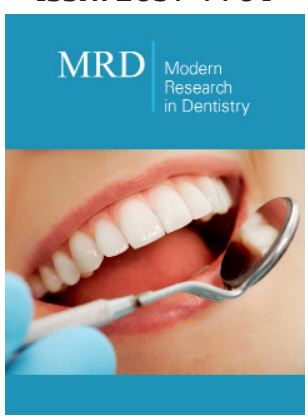

*1Corresponding author: Smriti Jagdhari Golhar, Assistant Professor, Department of Oral Medicine, India

Submission: 些 December 20, 2018

Published: 制 March 13, 2019

Volume 3 - Issue 4

How to cite this article: Smriti J G. SelfCare Management in Myofascial Pain Dysfunction Syndrome. Mod Res Dent. 3(4). MRD.000570.2019.

DOI: 10.31031/MRD.2019.03.000570

Copyright@ Smriti Jagdhari Golhar, This article is distributed under the terms of the Creative Commons Attribution 4.0 International License, which permits unrestricted use and redistribution provided that the original author and source are credited.

\author{
Smriti Jagdhari Golhar* \\ Department of Oral Medicine \& Radiology, India
}

Keywords: Myofascial pain dysfunction syndrome; Exercises

\section{Introduction}

Laskin introduced the term Myofascial pain-dysfunction syndrome (MPDS) and reemphasized that the disease entity is primarily in the muscles and only secondarily a joint problem. It is one of the commonest causes of chronic pain in oro-facial region. It is the most common form of temporomandibular disorders [1] that primarily involves the muscles of mastication. Most authors recommend a multidisciplinary approach for the treatment of MPDS. Because of the multifactorial nature of the MPDS, the treatment for any given patient will vary. These therapies include: Supportive therapy, Pharmacotherapy, Physical therapies [2-5]. In this, self care management is very important aspect to relive pain in day to day life. It includes patient education and guidelines, home exercise regime.

Patients must know about the disease in detail then only he understands its management part very well. Patient should be aware of their unconscious postural, swallowing, clenching habits and he must giveup his oral habits (eg, tooth clenching, chewing gum) from his daily routine which may be a source of muscle pain [3]. It might be eliminated by simple types of emotional stress therapy i.e. patient awareness, restrictive use, voluntary avoidance, relaxation therapy etc. [4]. Elimination of hard and sticky food helps to reduce loading forces on the joints which provides muscles relaxation. Diet is one of the most simple and important aspect of non surgical management. Patient should make a habit of placing the tip of the tongue behind the upper anterior teeth and keep the teeth slightly apart; keep this position when the jaw is not being working.

The purpose of exercise therapy is to maintain or increase mobility of soft tissues, muscles, and joints. Passive and active stretching movements are important in maintaining full range of motion. Isotonic and isometric exercises are taught to patients as part of a home program. These exercises regime includes opening, protrusion, and lateral excursion movement against resistance and are advice to do for 15 to 30 days. Manual Massage therapy is also helpful. Alternatively, hot and cold formantation is also advisable to the patients to reduce pain. It use as an adjacent therapy with exercise regime [4-9].

Guidelies for the patients for quick recovery [6-9].

1. Do not clench while driving, studying, doing computer work, athletic activities and reading.

2. Do not lean on the chin.

3. Patients should be lying in straight position not in lareral position (affected side).

4. During yawning, support your jaw by placing your hand over the chin.

5. Avoid eating those food that require wide opening. Patient used to chew bitateraly.

6. In case of acute pain avoid dental treatment, which is not required. 
Following these instructions is in intreast of patients for overall well-being.

Self-care program having home exercise plus pharmacotherapy, supportive therapy combination with self-massage is effective for improving pain-free daily activity functions. Patients are further required to visit hospital every month till the time of total recovery..

\section{References}

1. Mortazavi H, Javadzadeh A, Delavarian Z, Mahmoodabadi RZ (2010) Myofascial Pain Dysfunction Syndrome (MPDS). Iranian Journal of Otorhinolaryngology Autumn 22(61): 131-136.

2. Laskin DM, Block S (1986) Diagnosis and treatment of Myofascial Pain Dysfunction (MPDS) Syndrome J Prosthet Dent 56(1): 75-84.

3. Laskin DM, Greene SC (1972) Influence of the doctor-patient relation- ship on placebo therapy for patients with Myofascial Pain Dysfunction (MPDS) Syndrome. J Am Dent Assoc 85(4): 892-894.

4. Neill MC, Danzig WM, Farrar WM, Harold G, Moffett BC, et al. (1990) Craniomandibular (TMJ) disorders- The state of the art. Journal of prosthetic dentistry 44(4): 434-437.

5. Okeson JP (2003) Management of Temporomandibular Disorders and Occlusion ( $5^{\text {th }}$ edn) Mosby, USA.

6. Okeson JP (1995) Bells Orofascial pain ( $5^{\text {th }}$ edn) quintessence publication Co.

7. Burkit Oral medicine ( $9^{\text {th }}$ edn) JB Lippincott Co, USA, pp. 301-321.

8. Dommerholt J (2006) Myofascial pain syndrome in the craniomandibular region madrid, Ripano, USA, 4: 564-581.

9. Moody PM, Okeson JP, Calhoun TC, Kemper JT (1981) Stress-pain relationship in MPD syndrome patients and non-MPD syndrome patient. Journal of prosthetic dentistry 45(1): 84-88. 